University of Nebraska - Lincoln

DigitalCommons@University of Nebraska - Lincoln

Agronomy \& Horticulture -- Faculty Publications

Agronomy and Horticulture Department

1930

\title{
Alfalfa Production in a Grassland Climate
}

J. E. Weaver

University of Nebraska-Lincoln

Follow this and additional works at: https://digitalcommons.unl.edu/agronomyfacpub

Part of the Plant Sciences Commons

Weaver, J. E., "Alfalfa Production in a Grassland Climate" (1930). Agronomy \& Horticulture -- Faculty Publications. 465.

https://digitalcommons.unl.edu/agronomyfacpub/465

This Article is brought to you for free and open access by the Agronomy and Horticulture Department at DigitalCommons@University of Nebraska - Lincoln. It has been accepted for inclusion in Agronomy \& Horticulture -Faculty Publications by an authorized administrator of DigitalCommons@University of Nebraska - Lincoln. 


\section{Alfalfa Production in a Grassland Climate}

The importance of root extent and activities in relation to the supply of subsoil moisture has again been clearly demonstrated. In fact, it has been shown to be the chief problem in the continued production of alfalfa in a grassland climate. ${ }^{1}$

Studies extending over a period of I $_{5}$ years ${ }^{2}$ have shown that the native species of the tall-grass prairie never exhaust the water supply below that available for plant growth, except rarely in the shallower soil. The subsoil is always moist, and plants root deeply. Of 43 species typically representative of the flora, only 44 per cent absorb almost entirely in the first 2 feet of soil; 2 I per cent have roots extending well below 2 feet but seldom beyond 5 feet; but 65 per cent have roots that reach depths quite below 5 feet, a penetration of 8 to 12 feet being common, and a maximum depth of over 20 feet sometimes being attained. There is sufficient rainfall to wet the soil very deeply, but it is not too wet for good aeration, while aerial conditions promote high transpiration. This results in deep root penetration.

Many of the species that absorb from the deeper subsoil are legumes. These are always interspersed among the grasses, and, even where most abundant, they do not grow in dense stands like the cultivated legumes. The continued growth of the grasses throughout the season, and the late period of flower and seed production among most of them, indicate a long, favorable growing season uninterrupted by a deficiency of soil moisture. The deep, only slightly leached and usually acid-free soils of the tall-grass prairie furnish the most productive region for agriculture, a fact fully substantiated by the excellent yields of wheat, oats, and corn. But when these crops are rotated with alfalfa, too great demands are made upon the water supply, and the subsoil moisture is rather permanently exhausted.

The roots of alfalfa develop rapidly, growing at the rate of 6 or more feet per year for at least 2 or 3 years, ultimately reaching depths of 30 feet or more. ${ }^{3}$ A 2-year-old alfalfa meadow has been shown to lower the water

1 Kiesselbach, T. A., Russel, J. C., and Anderson, Arthur. The significance of subsoil moisture in alfalfa production. Jour. Am. Soc. of Agron., 21: 24I-268. 1929.

${ }^{2}$ Weaver, J. E. Root development of field crops. New York. McGraw-Hill Book Company, I926.

3 Loc. cit., footnote 2. 
content to a depth of 25 feet, and ro-year-old ones to 33 feet. The excellent growth and high yields of the plants during the first 3 or 4 years are practically independent of the amount of rainfall, since they are using the water stored in the subsoil. Thereafter they decline and become largely dependent upon the rainfall. But, where alfalfa has previously grown, even as remotely as ${ }_{5} 5$ years, the yields appear to be dependent upon rainfall from the very beginning, and are never as high as during the early years on land where this crop has not previously been grown. For example, a 6 -year-old alfalfa meadow reached its maximum production during the third year $(7.2$ tons of cured forage per acre), yields thereafter being curtailed by the depletion of the subsoil moisture. During the fifth and sixth years the yields were only 2.0 tons per acre, although a good healthy stand persisted. That the decrease was not due to lack of soil fertility was shown by the addition of various fertilizers. Irrigating a portion of the field during the sixth year increased the yield nearly three-fold.

The water demands of an acre of alialfa greatly exceed that of native vegetation. They also greatly exceed that of corn, wheat, or oats, where the plants are either wilely spaced or the crop matures early. To grow a ton of cured alfalfa hay in Nebraska requires 858 tons of water. ${ }^{4}$ This is 2 to 3 times as great as the amount needed for an equal weight of the cereal crops. It has been calculated that approximately 27 acre inches of water are required annually to supply the transpiration demands of an alfalta meadow during its second to sixth year of growth. During the second $t_{1}$ the fourth year, water requirement considerably exceeds precipitation. This extra requirement is met by the moisture of the sulssoil which appears to have lost during the 6-year period 32.9 acre inches. At the end of 2 years the available water was reduced to 2.5 per cent down to a depth of 7 feet : after 3 years of growth to a depth of $I_{5}$ feet: and after 6 years to 25 feet. To maintain the high yield attained the third year would reguire +6 inches of water per year.

The restoration of this sulssoil moisture is extremely slow. "During I $_{5}$ years of cropping to cercal crops following the breaking up of an established upland alfalfa meadlow, very little moisture had accumulated beyond the seventh foot. The arerage increase in moisture content from the fifth to the thirty-fifth foot appears to have been o.t per cent. It this rate approximately 225 years would be required to restore the sulsoil moisture removed by six years of cropping to alfalfa." On such land a new crop of alfalfa (planted 8 years later) yielded on an average only 5.5 per cent as much as a corresponding adjacent meadow on land that had not previously grown this legume.

I new crop of alfalfa on such soil showed undersized taproots that branched profusely at depths of 5 to 1 if feet into networks of fine roots that

${ }^{4}$ Kiesselbach, T. A., and Anderson, A. Alfalfa investigations. Nebr. Agr. E.rp. Sta. Res. Bull. 36: I-I25. I026. 
clung to the faces of the many fissures that characterize the deep, dry subsoil. This is quite in contrast to the normal sturdy taproots with many fine branches throughout the soil mass. That roots in old fields actually absorb water at great depths was shown by irrigating in a trench so feet deep. This resulted in a much more vigorous growth of the irrigated plants.

"Subsoil moisture depletion is not to be looked upon as harmful to succeeding cereal crops, since . . . very little moisture is ever elevated by capillarity from regions beyond the root zone." But "invariably, upland soils that are not irrigated will for years to come be deficient in subsoil moisture for a highly productive cropping to alfalfa the second time."

The results of these findings made at Lincoln, Nebraska, are probably applicable over an extensive territory wherever reasonably sinilar soil and climatic conditions exist. In mixed prairie, where less subsoil moisture is available, the problem is even more serious. Even in climatic tall-grass prairie the effective rainfall is usually insufficient in itself for a very high yield of alfalfa, and ordinarily is not in excess of the current needs of cereal crops. As a general practice, to maintain high yields, it would be better to shift the alfalfa to a new field where the subsoil moisture supply is yet intact and relatively large yields are assured.

Cultural practices which may be followed in the restoration of subsoil moisture are still to be determined. "The feasibility of summer fallow is debatable since a single season of such fallow cannot be expected to add greatly to the deep-seated subsoil moisture supply, and successive fallowing during a period of years would seem impracticable." It may be that, when the comparative values of red clover, alsike clover, sweet clover, or other leguminous crops for these soils clepleted in subsoil moisture are determined, alfalfa production will be greatly reduced or confined to low-lying ground or meadows where surface or subirrigation is practiced. The problems involved are of great scientific and practical interest, and furnish an outstanding example of the need of a clear understanding of plant activities and environment in problems of crop production.

$$
\text { J. E.. WEAVER }
$$

UNIVERSity OF NEBRASKa 